\title{
層流境界層中の周期低速ストリークの不安定性に関する実験的研究*
}

\author{
小西 康 郁*1, 浅 井 雅 人 $^{* 2}$
}

\section{Experimental Investigation of the Instability of Spanwise-periodic Low-speed Streaks in a Laminar Boundary Layer}

\author{
Yasufumi KONISHI and Masahito ASAI*3 \\ ${ }^{* 3}$ Dept. of Aerospace Eng, Tokyo Metro. Inst. Tech., \\ 6-6 Asahigaoka, Hino-shi, Tokyo, 191-0065 Japan
}

\begin{abstract}
The streak instability is examined experimentally through artificially producing spanwiseperiodic low-speed streaks in a flat-plate laminar boundary layer. The observation focuses on sinuous instability modes which are responsible for the regeneration of quasi-streamwise vortices in near-wall turbulence. Effects of the interaction between disturbances developing along the neighboring streaks on the instability are examined through comparing the disturbance development for various streak spacing. The instability characteristics are also compared with those for a single lowspeed streak. The development of subharmonic modes does not strongly depend on the streak spacing and they grow with almost the same growth rate as that for the single streak. By contrast, the development of fundamental modes is very sensitive to the streak spacing, and is completely suppressed when the streak spacing is less than 2.5 times the streak width.
\end{abstract}

Key Words : Flow Instability, Boundary-Layer Transition, Wall Turbulence, Low-Speed Streaks

\section{1. 粕 言}

壁面に沿うせん断乱流おいては，壁近傍に存在 する低速ストリークの発達や崩壊が乱流構造の生 成・維持に大きな役割を果たしていると考えられ

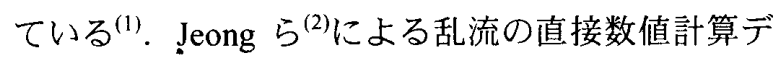
一タ ${ }^{(3)}$ の詳細な解析により，そのような壁近傍ス トリークに伴うジグザグ状に連なった縱渦構造が 同定され，その生成機構としてストリーク不安定 が注目されている(4)、また，平面クエット流や平 面ポアズイユ流における数值実験 ${ }^{(5)}$ (7)では, 壁近 くの縦渦とストリークの再生成サイクルが観察さ れている.

境界層遷移においても, ストリークの発達とそ の不安定性の重要性が指摘されている．強い主流 乱れによるバイパス遷移 ${ }^{(8)(9)}$ では，T-S 波動が成長 する前に直接ストリーク構造が発達し，その崩壊 が乱流斑点の発生を促す，凹面境界層のゲルトラ

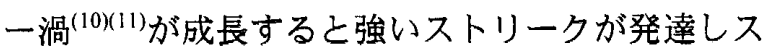
トリーク不安定（二次不安定）に導く.さらに,

* 原稿受付 2002 年 10 月 9 日.

*1 東京都立科学技術大学大学院 (五191-0065 日野市旭が丘 66).

*2 正員, 東京都立科学技術大学工学部。

E-mail : masai@cc.tmit.ac.jp
T-S 波動の成長から始まる遷移 ${ }^{(12)(13)}$ においても， 遷移後期段階になるとやはり壁近くにストリーク 構造が発達し, それが崩壊して壁乱流の芽が生ま れる。

低速ストリークは, 壁に垂直方向の混合層型速 度分布のケルビン・ヘルムホルツ不安定と, スパ ン方向の後流型速度分布の不安定性の両者を併せ 持つと考えられる. それらは, 低速ストリーク上 のせん断層の対称的な渦（ヘアピン状又はアーチ 状）への巻き上がりに導く Varicose モードと, ス トリークの蛇行に導く Sinuous モードの増幅を支 配する，ただし，これらの増幅特性は，ストリー クの幾何学形状やスケールに支配されるので(14)(15), ストリーク不安定を詳細に調べるためには, 不安 定特性を支配するパラメータを自由に設定できる 実験デザインを行うことが重要である.この点に 関し, Asai ら ${ }^{(16)}$ は, 排除厚さ程度の高さの小さな 網片を壁に垂直に立て単一の人工低速ストリーク を実現し，それに周期擋乱を与えて，ストリーク の崩壊に導く不安定性やそれに伴う組織渦構造の 生成過程を実験的に調べ, Varicose モードと Sinuous モードに対する線形不安定特性を詳細に 示した. しかしながら，現実に存在する壁近傍ス トリークは単一ではなく，スパン方向にある平均 
間隔（壁乱流では壁単位で 100 程度）で並んだス トリーク列として現れる。 そこで本研究では, Asai ら ${ }^{(16)}$ と同様の網片を用いた方法で，スパン方 向に周期的に並んだストリーク列を実現して，ス トリーク列の不安定性を調べ，単一の低速ストリ 一クの結果との比較を行った.

\section{2. 実験装盢及び方法}

実験は，測定部断面 $400 \mathrm{~mm} \times 400 \mathrm{~mm}$ の吹き出 し式低乱風洞で行われた。図 1 に実験装置の概略 を示す. 風洞は, 拡散胴の 3 枚の剥離防止用網, 集合胴内の 5 枚の整流網と八ニカムを備えており, 縮流部の絞り比は 9 である. 風洞測定部の乱流強 度は主流速度の $0.1 \%$ 以下である。境界層平板は， 厚さ $10 \mathrm{~mm}$, 長さ $1100 \mathrm{~mm}$ のアクリル板であり, 前縁は長軸短軸比 $12: 1$ の棈円形に加工してある. 座標系は, 前縁から下流方向に $x$, 平板上面に垂 直上向きに $y$, スパン方向に $z$ （スパン中心を $z=$ 0) とする.

前縁から $500 \mathrm{~mm}$ 下流位置 $\left(x_{0}=500 \mathrm{~mm}\right)$ に, 高 さ $2.5 \mathrm{~mm}$, 幅 $6 \mathrm{~mm}$ の網片 (40 メッシュ, 開口比 70\%）を，壁に垂直に取り付けた。網のスパン間 隔は， $12 \mathrm{~mm}, 15 \mathrm{~mm}$ 又は $18 \mathrm{~mm}$ の 3 種類であり， それぞれ 21 個，18 個，15 個，スパン方向に一列 に並べてある，網のすぐ下流には，ストリーク不 安定を支配する Varicose モードと Sinuous モード を励起するための小孔が設けられている．各網片 の $8.5 \mathrm{~mm}$ 下流の中央 $\mathrm{z}$ 位置にある小孔（直径 $3 \mathrm{~mm}$ ）は Varicose モ一ドの励起用であり, 各網の 左右両端の $13.5 \mathrm{~mm}$ 下流位置 $\left(x-x_{0}=13.5 \mathrm{~mm}\right)$ の 小孔（直径 2mm）は Sinuous モードを励起するた めのものである. それぞれの小孔はビニールホー スでラウドスピーカーにつながれ，単一周波数の 正弦波信号で駆動し周期摚乱を励起する. 小孔か ら導入される垂直方向速度変動の振幅は主流速度 の $0.1 \%$ 以下の微弱なものである.

本実験では，壁乱流の壁近傍領域においてより 支配的と考えられている Sinuous モードにのみ注 目している. 従って, Varicose モード励起用の小 孔（直径 $3 \mathrm{~mm}$ ）はスコッチテープにより閉じて ある. Sinuous モードを励起するための網の左右 一対の小孔は別々のスピーカーにつながれており， $180^{\circ}$ 位相が異なる正弦波信号で駆動することに より Sinuous モードを励起することができる、ま た,ここでは 2 種類の Sinuous モードについて增
幅特性を調べた。一つは，粯乱のスパン方向の基 本波長がストリークのスパン間隔入と一致する基 本波数モード（Fundamental Mode）であり, 他方 は，ストリーク間隔の 2 倍のスパン波長 $(2 \lambda)$ を 持つ分調波数モード（Subharmonic Mode）である. それぞれのモードが増幅すると, 図 2 に示すよう な 2 種類の低速ストリークの蛇行を生じる.

平均速度 $U$ および変動 $u$ の測定は熱線風速計で 行われた. 熱線の受感部は, 直径 $0.5 \mu \mathrm{m}$, 長さ $1 \mathrm{~mm}$ のタングステン線である. 熱線プローブは 3 軸トラバース装置により 3 方向に自由に移動でき る. 実験の主流流速 $U_{\infty}$ はすべて $4 \mathrm{~m} / \mathrm{s}$ である. 網
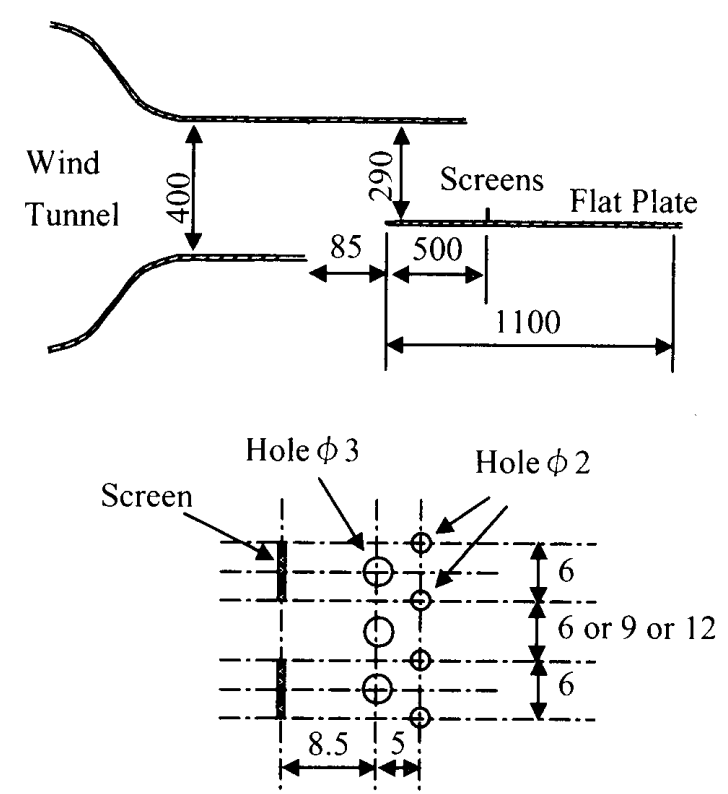

Fig. 1 Experimental setup (dimensions in $\mathrm{mm}$ ).

(a)

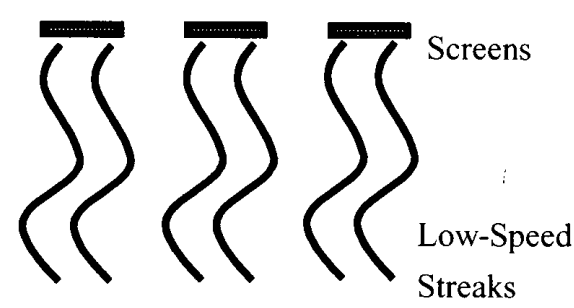

(b)

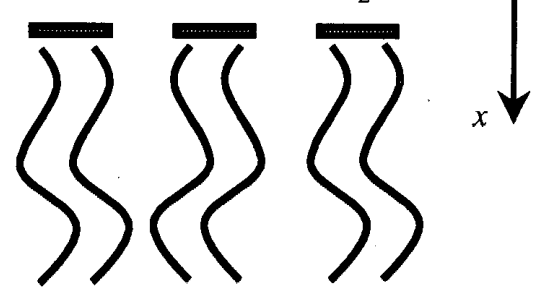

Fig. 2 Schematic of fundamental and subharmonic sinuous modes. (a) fundamental mode, (b) subharmonic mode. 
を取り付けない場合の境界層はブラジウス流に一 致し，その時の境界層排除厚さ $\delta$ *は網を取り付 ける $x$ - $x_{0}=500 \mathrm{~mm}$ 位置で約 $2.4 \mathrm{~mm}$, 排除厚さに基 ブくレイノルズ数 $R^{*}$ は約 650 である. 網片の高さ はこのブラジウス境界層の排除厚さに設定してあ る.

\section{3. 低速ストリークの平均速度場}

図 3 は, 網のスパン間隔 $\lambda=12 \mathrm{~mm}$ の場合につ いて, 網の下流に発達する低速ストリーク列を平 均速度 $U$ の等値線で表している. 図(a)は $y=3 \mathrm{~mm}$ 位置での $x-z$ 断面内の速度分布, 図(b)は. $x-x_{0}=$ $60 \mathrm{~mm}$ 位置での $x-y$ 断面内の速度分布を表してい る. 図(a)のように, 網片の下流に低速領域, 網と 網の間に高速領域が存在しており，それらは互い に干渉することなく，等間隔に並んだストリーク 列が実現されている。，また，図(b)より，低速領域 の高さについても，導入されたストリーク列の周 期性は極めて良好であることがわかる。ただし， 流下につれて各低速ストリークが徐々にではある が弱まっていく様子が見られる。これは，ストリ 一ク周りのせん断層の粘性拡散によるものである. 図の最下流位置 $x-x_{0}=200 \mathrm{~mm}$ での乱れ強さは, $u_{m}^{\prime} / U_{\infty}=1 \%$ 以下であり, 層流状態のストリークが 維持されている. 人工的に擋乱を導入しない限り 観察範囲内で乱流に遷移することはない.

図 4 は, $x-x_{0}=50 \mathrm{~mm}$ 位置での平均速度 $U$ の $y$ 方向 分布と $z$ 方向分布である. 図のように, $z=0$ 位置, 即ち低速領域の中心（網のスパン中心）位置では, tanh 関数で近似される变曲型速度分布を持ち, 高速 域に対応する網と網の中間位置 $(z=6 \mathrm{~mm})$ の速度 一分布は, ブラジウス分布より僅かにふくれている程 度である. $z$ 方向には, それぞれの網の下流に発達 する後流型速度分布が周期的に繰り返し, その結果, 正弦波状に変化した速度分布を示している. スパン 間隔の広い $\lambda=15 \mathrm{~mm}$ 及び $18 \mathrm{~mm}$ の網配列の場合にお いても同様のストリーク構造を導入できる. 図 5 は, $\lambda=15 \mathrm{~mm}$ と $18 \mathrm{~mm}$ の網配列の場合について, $x-x_{0}=$ $60 \mathrm{~mm}$ 位置での平均速度 $U$ の $x$-y 断面内分布を図示 している. 網間隔を広げると, 網の両端での加速が 網間全体に及ばないため, 隣り合う網の中間ではブ ラジウス速度分布に近い領域が広がるが，各網片の 下流に形成された個々の低速ストリークに注目する と, 低速ストリークを横切る速度分布形状（y 方向 には $\tanh$ 関数形分布, $z$ 方向には後流型分布）及び (a)

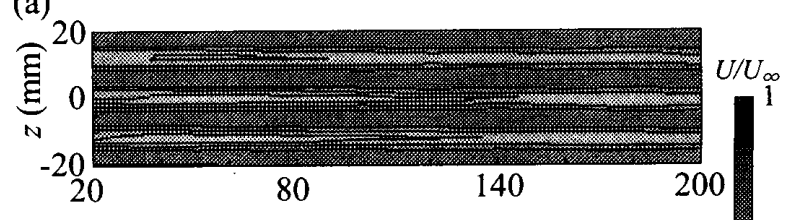

(b)

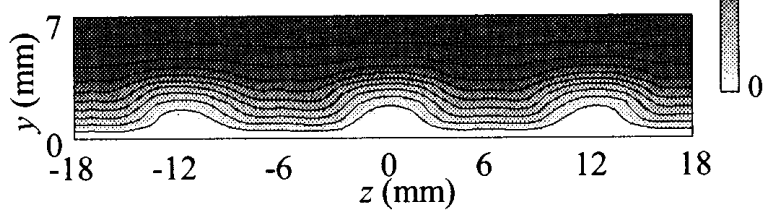

Fig. 3 Low-speed streaks downstream of the screens for $\lambda=12 \mathrm{~mm}$. Iso-velocity contours: (a) $x-z$ plane at $y=3 \mathrm{~mm}$, (b) $y-z$ plane at $x$ $x_{0}=60 \mathrm{~mm}$.
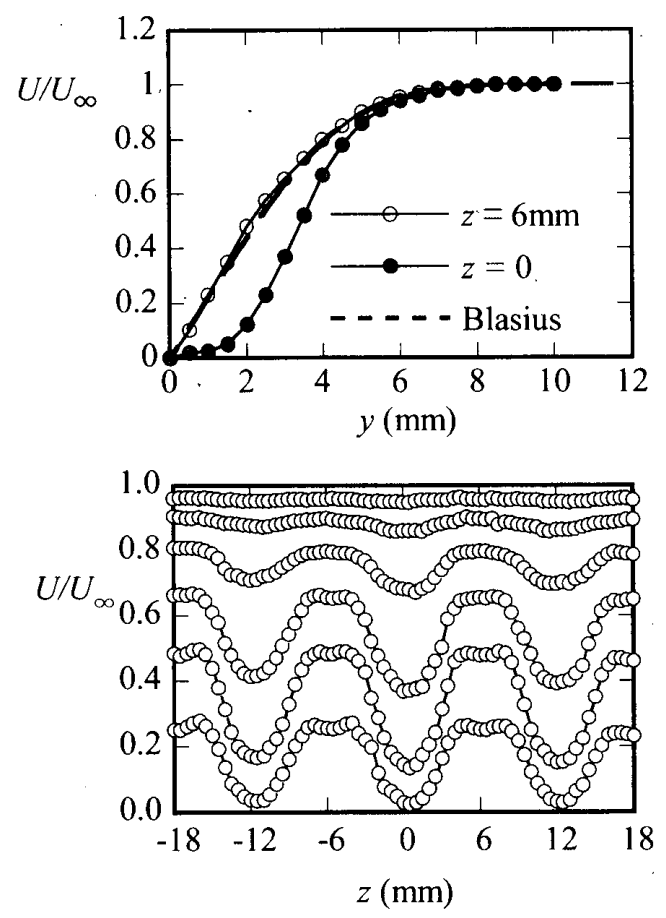

(b)

Fig. $4 y$-and $z$-distributions of mean velocity $U$ at $x-x_{0}=50 \mathrm{~mm}$ for $\lambda=12 \mathrm{~mm}$. (a) $y$-distributions, (b) $z$-distributions at $y=5 \mathrm{~mm}, 4 \mathrm{~mm}, 3 \mathrm{~mm}, 2 \mathrm{~mm}$ and $1 \mathrm{~mm}$ (from top).

(a)

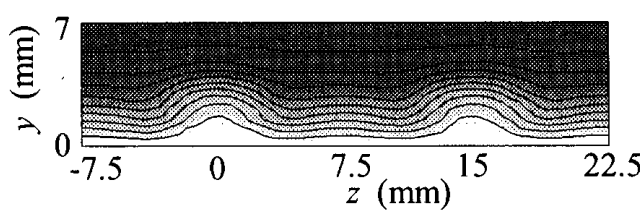

(b)

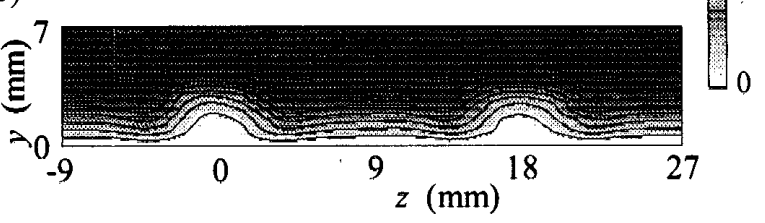

Fig. 5 Iso-velocity contours in the $y-z$ plane at $x$ $x_{0}=60 \mathrm{~mm}$. (a) $\lambda=15 \mathrm{~mm}$, (b) $\lambda=18 \mathrm{~mm}$. 
低速領域の幅は， $\lambda=12 \mathrm{~mm}$ の場合とほとんど同一 である. また，単一の網の下流に発達する低速スト リークの速度分布も測定してあるが，それともほと んど違いがない. 従って，これらの周期ストリーク 並びに単一ストリークの不安定特性の比較により, 低速ストリーク間の相互作用がストリーク不安定に 如何に影響するかを調べることができると期待され る.

\section{4. 低速ストリークの不安定性}

周期低速ストリークに前述の人工摚乱を加え， Sinuous モードを励起した. まず, 励起される基 本波数モ一ド (Fundamental mode) と分調波数モ 一ド（Subharmonic mode）の構造を説明する. 図 6 は, $\lambda=18 \mathrm{~mm}$ のストリークについて,$x$ $x_{0}=60 \mathrm{~mm}$ における基本波数モードと分調波数モ一 ドの $u$ 変動実効值 $u^{\prime} の y-z$ 断面分布である. ただ し, それぞれ面内の変動の最大値によって正規化 してある. 図のように, 基本波数モードと分調波 数モードの振幅分布は, いずれの $u$ 変動も, 低速 ストリークの両端の垂直せん断層上で最大振幅を とる. 図 7 は， $u$ 変動分布を $x-z$ 断面で見たもの である.いずれも $u$ 変動振幅が最大となる $y=2.5 \mathrm{~mm}$ 高さに沿って測定されている. 個々のス トリークに注目すると, $180^{\circ}$ 位相のずれた変動 が対となって, 発達していく様子がわかる. 基本 波数モードは, 隣り合うストリーク上で同位相で あり, 従ってストリーク間隔えと同じ基本波長を 持つが，分調波数モードは，隣り合うストリーク 間で $180^{\circ}$ の位相差を有し, ストリーク間隔の 2 倍の基本波長を持つことが確認できる。 また，摚 乱の位相速度は, 最大振幅位置の平均速度 $\left(0.6 U_{\infty}\right)$ にほぼ一致することを追記する．この ように，本実験手法により，それぞれのモードを 確実に励起できることがわかる。これら基本波数 モード及び分調波数モードについて増幅特性を調 ベる.

まず，基本波数モードの增幅特性について述べ る. 図 8 は， $\lambda=18 \mathrm{~mm}$ のストリークに対して, 種々の周波数の基本波数モードの増幅特性を $u$ 変 動（励起周波数成分）の最大実効值 $u_{\mathrm{m}}^{\prime}(y-z$ 断面 内の最大振幅）の $x$ 方向変化で示している. 図の ように，擋乱増幅は周波数選択性を示し， $45 \mathrm{~Hz} 80 \mathrm{~Hz}$ の範囲で指数增幅が見られる.ただし， 増幅率はそれほど大きくなく,$x-x_{0}=200 \mathrm{~mm}$ まで
に 4 倍の振幅に達する程度である，比較のため,

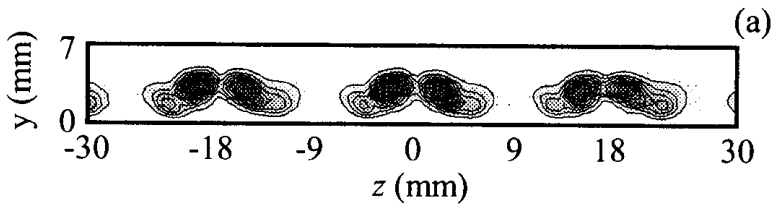

(b)

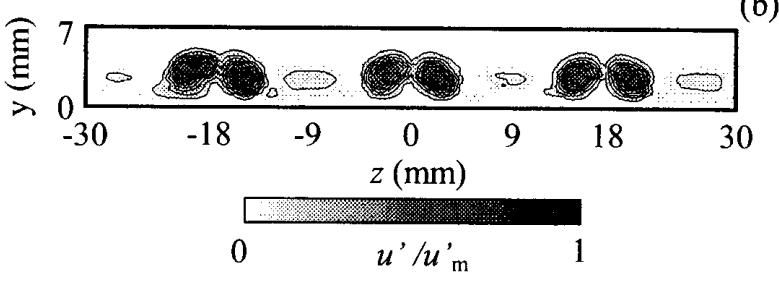

Fig. 6 Amplitude distributions of sinuous modes in the $y-z$ plane at $x-x_{0}=60 \mathrm{~mm}$ for $\lambda=18 \mathrm{~mm}$. (a) fundamental mode $(f=60 \mathrm{~Hz})$, (b) subharmonic mode $(f=60 \mathrm{~Hz})$.
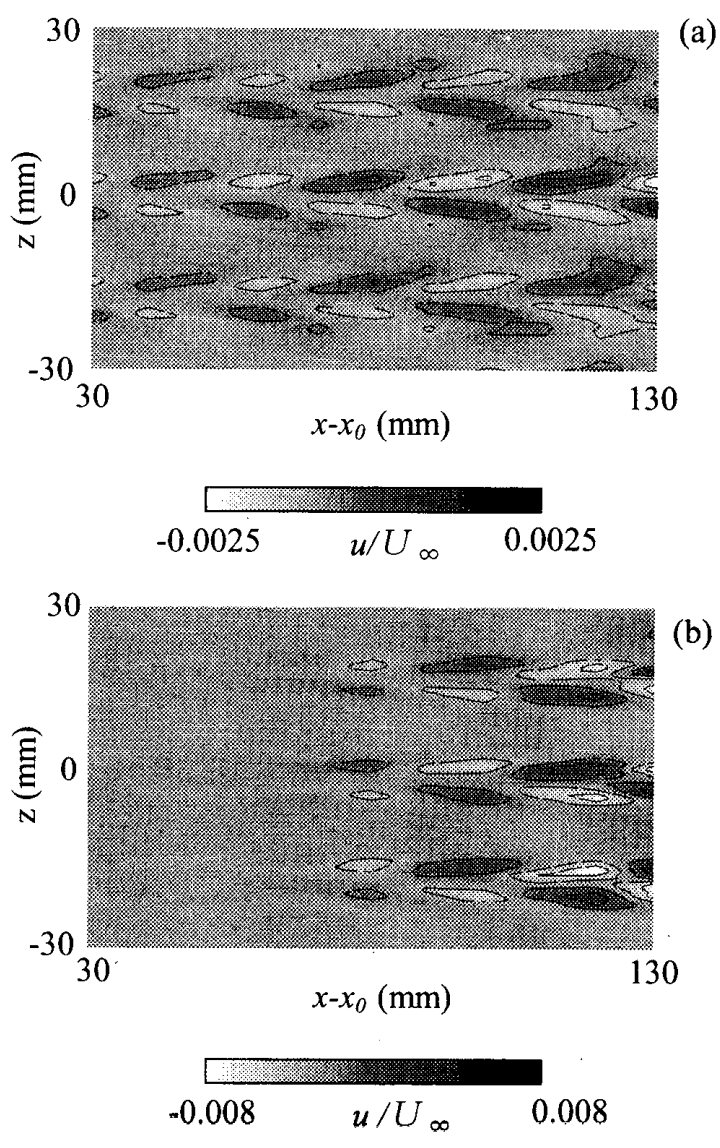

Fig7 $u$-fluctuation component of sinuous modes in the $x-z$ plane at $y=2.5 \mathrm{~mm}$ for $\lambda=18 \mathrm{~mm}$. (a) fundamental mode $(f=60 \mathrm{~Hz})$, (b) subharmonic mode $(f=60 \mathrm{~Hz})$. 
同一サイズの網片を用いて単一ストリークの不安 定特性を求めると, 図 9 のように, すべての周波 数の擋乱に対してはるかに大きな増幅率で増幅す る. 最大増幅周波数は両者共同じで $60 \mathrm{~Hz}$ 付近で ある.また， $x-x_{0}=100 \mathrm{~mm}$ を越えたあたりから増 幅が徐々に鈍化するのは，ストリークが粘性拡散 により弱くなるためである.

このように，ストリーク構造の周期性はその不 安定性を顕著に抑制する方向に働く，実際，スト リーク間隔入を少し小さくするだけで全く増幅が 止まる。例えば，図 10 は，最大增幅擋乱 $(60 \mathrm{~Hz})$ の増幅特性が, $\lambda=15 \mathrm{~mm}$ 及び $12 \mathrm{~mm}$ の ストリークではどのように変わるかを示している. 図のように，ストリーク間隔が入 $=15 \mathrm{mmn}$ に減少 しただけで, 最も不安定な $60 \mathrm{~Hz}$ 摚乱でさえ増幅 を示さずほぼ中立な状態になる．さらにストリー ク間隔の小さな $\lambda=12 \mathrm{~mm}$ では擋乱は減衰に転じる. もちろん他の周波数の擋乱についてもすべて減衰 することを確認している。 このように, 基本波数 モードは，ストリーク間隔に極めて敏感であり， 今回の形状の低速ストリークでは，ストリーク不 安定が起きる限界の入は $15 \mathrm{~mm}$ であることがわか る. 低速ストリークの幅（低速ストリークを横切 る $U$ の後流型 $z$ 方向分布の半值幅）は網の横スケ 一ル $s=6 \mathrm{~mm}$ 程度であるので, ストリーク間隔と ストリーク幅の比入s で言えば，基本波数モ一ド が増幅可能な臨界值は約 2.5 である。

次に, 分調波数モ一ドの増幅特性について述べ る. 図 11 は， $\lambda=12 \mathrm{~mm}$ のストリークにおける各 翼乱周波数に対する変動の最大実効值の $x$ 方向変 化を示している，基本波数モ一ドと異なり，分調 波数モードでは，この最も間隔の狭い $\lambda=12 \mathrm{~mm} の$ ストリークにおいても増幅を示し， $200 \mathrm{~mm}$ 下流 でも増幅を持続する．最大増幅摚乱の周波数は $60 \mathrm{~Hz}$ 付近であり, 単一ストリークにおける最大 増幅周波数と一致する. また，堌幅率も，図 9 に 示した単一ストリークの場合の擋乱とそれほど違 いがないように見える。

図 12 は, $\lambda=12 \mathrm{~mm}, 15 \mathrm{~mm}, 18 \mathrm{~mm}$ の各ストリ 一クについて，最大増幅周波数を与える $60 \mathrm{~Hz}$ 靦 乱の増幅特性を単一ストリークの結果と比較した ものである、ストリーク間隔の最も広い $\lambda=18 \mathrm{~mm}$ の場合においては, 単一ストリークの場合とほと んど完全に一致した増幅率を示す， $\lambda=15 \mathrm{~mm}$ 及び $12 \mathrm{~mm}$ のようにストリーク間隔が狭くなっても, 僅かに増幅率が低下する程度である。
このような基本波数モードと分調波数モードの 増幅特性のストリーク間隔に対する依存性の違い は, 両モードの構造の違いによるものであると推 測される. 図 6 に示した 2 つの振幅分布を比較す ると, 基本波数モードの振幅分布は高速域まで広 がっていて，その結果，ストリーク間隔が狭まる と, 基本波数モードは, 隣り合うストリークに発 達する擋乱構造が干渉し, 発達がより大きな影響

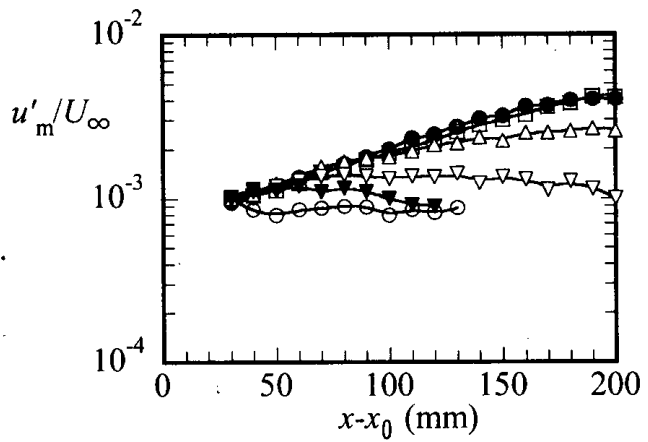

Fig. 8 Development of fundamental modes for $\lambda=18 \mathrm{~mm} . \bigcirc 30 \mathrm{~Hz} . \square 45 \mathrm{~Hz} . \bigcirc 60 \mathrm{~Hz} . \triangle 70 \mathrm{~Hz}$. $\nabla 80 \mathrm{~Hz} . \nabla 90 \mathrm{~Hz}$.

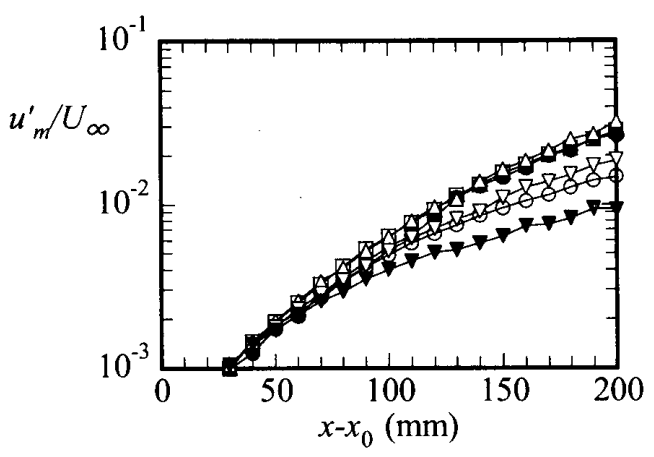

Fig. 9 Development of sinuous modes for the single streak case. $\bigcirc 30 \mathrm{~Hz} . \square 45 \mathrm{~Hz} .60 \mathrm{~Hz}$. $\triangle 70 \mathrm{~Hz} . \nabla 80 \mathrm{~Hz} . \nabla 90 \mathrm{~Hz}$

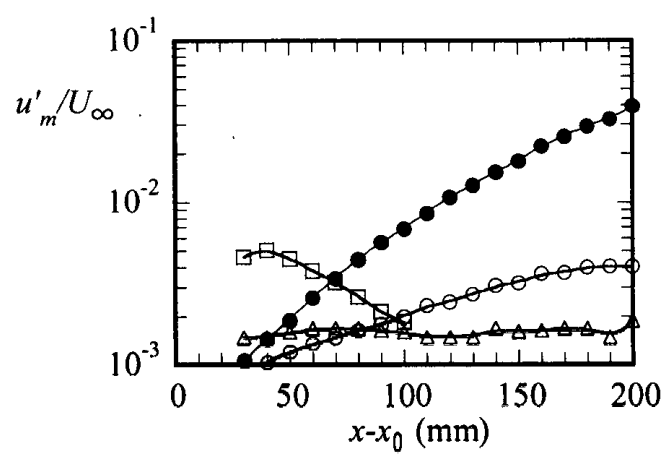

Fig. 10 Comparison of development of fundamental modes excited at $f=60 \mathrm{~Hz}$. $\square \lambda=12 \mathrm{~mm}$. $\triangle \lambda=15 \mathrm{~mm}$. $\bigcirc=18 \mathrm{~mm}$, single streak. 
を受けると考えられる.

\section{5. 結}

本研究では, 網片を用いることにより層流境界 層中に人工的に周期的な低速ストリーク列を作り， ストリークの蛇行に導く Sinuous モードに対する 不安定特性を実験的に調べた。 また, 単一低速ス トリークの場合の結果と比較した. 主な結果は次 の通りである.

1）ストリーク間隔の 2 倍の基本波長を持つ分調 波数モード（Subharmonic mode）は，ストリー ク間隔に敏感でなく，単一ストリークの場合 とほとんど変わらない増幅特性を示す。

2）基本波数モード（Fundamental mode）は，分調 波数モードに比べて増幅率が小さく，また， ストリーク間隔に強く依存する，ストリーク 間隔の減少とともに増幅が急速に弱くなり， ストリーク間隔がストリーク幅の 2.5 倍より小 さくなると増幅できない.

\section{謝辞}

本研究は, 部分的に学術振興会科学研究費補助 金基盤研究 C（13650963），文部科学省科学研究 費特定領域研究 B（12125203），並びに東京都特 定学術研究費の援助を受けた。

\section{引用 文 献}

(1) Robinson, S.K., Ann. Rev. Fluid Mech. 23 (1991), 601-639.

(2) Johansson, A.V., Alfredsson, P.H. and Kim, J., J. Fluid Mech. 224, (1991), 579-599.

(3) Jeong, J., Hussain, F., Schoppa, W. and Kim, J., J. Fluid Mech. 332 (1997), 185-214.

(4) Waleffe, F. and Kim, J., Self-Sustaining Mechanisms of Wall Turbulence, Chap. 3 (1997), 309-332.

(5) Hamilton, J.M., Kim, J. and Waleffe, F., J. Fluid Mech. 287 (1995), 317-348.

(6) Itano T. and Toh S., J. Phys. Soc. Japan 70 (2001), 703-716.

(7) Kawahara, G. and Kida, S., J. Fluid Mech. 449 (2001) 291-300,

(8) Morkovin, M.V. and Reshotko, R., LaminarTurbulent Transition (eds. R. Michel and D. Arnal), Springer-Verlag (1990), 3-39.

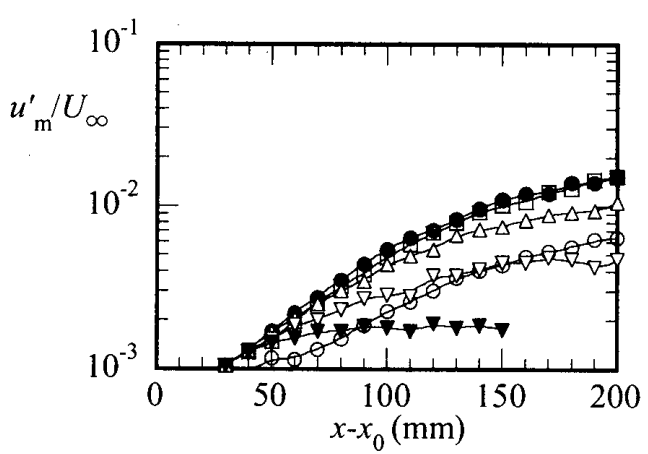

Fig. 11 Development of subharmonic modes for $\lambda=12 \mathrm{~mm} . \bigcirc 30 \mathrm{~Hz} . \square 45 \mathrm{~Hz} .660 \mathrm{~Hz} . \triangle 70 \mathrm{~Hz} . \nabla$ $80 \mathrm{~Hz} . \nabla 90 \mathrm{~Hz}$.

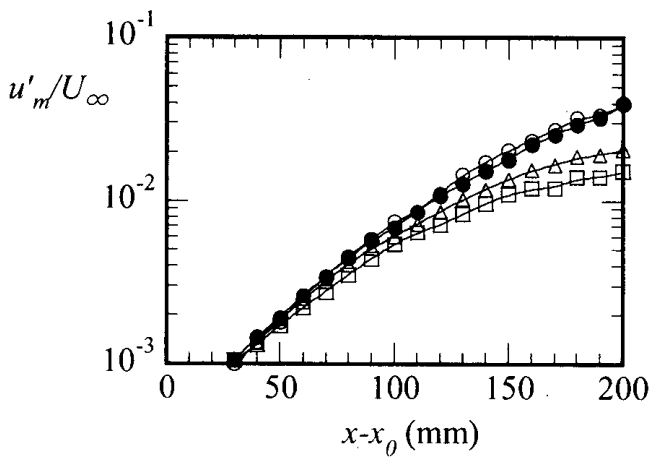

Fig. 12 Comparison of development of subharmonic modes excited at $f=60 \mathrm{~Hz} . \square \lambda=12 \mathrm{~mm} . \Delta \lambda=15 \mathrm{~mm}$. $\lambda=18 \mathrm{~mm}, \bigcirc$ single streak.

(9) Matsubara, M. and Alfredsson, P.H., J. Fluid Mech. 430 (2001), 149-168.

(10) Swearingen, J.D. and Blackwelder, R.F., J. Fluid Mech. 182 (1987), 255-290.

(11) Li, F. and Malik, M.R., J. Fluid Mech. 297 (1995), $77-100$

(12) Nishioka, M. and Asai, M., Turbulence and Chaotic Phenomena in Fluids (ed. T. Tatsumi), Elsevier (1984), 87-92.

(13) Asai, M. and Nishioka, M., Theoretical and Applied Mech. 1996 (eds. T. Tatsumi et al.), Elsevier (1997), 121-138.

(14) Schoppa, W. and Hussain, F., Fluid Dyn. Res. 26 (2000), 119-139.

(15) Andersson, P., Brandt, L., Bottaro, A. and Henningson, D., J. Fluid Mech. 428 (2001), 29-60.

(16) Asai M., Minagawa M. and Nishioka, M., J. Fluid Mech. 455 (2002), 289-314. 